\title{
Molecular Epidemiology of HIV-1 in Santa Catarina State Confirms Increases of Subtype C in Southern Brazil
}

\author{
Dayse Locateli, ${ }^{1}$ Patrícia H. Stoco, ${ }^{2}$ Artur T.L. de Queiroz, ${ }^{3,4}$ Luiz C.J. Alcântara,,${ }^{3,4}$ \\ Luiz G.E. Ferreira, ${ }^{5}$ Carlos R. Zanetti, ${ }^{1}$ Rosângela Rodrigues, ${ }^{6}$ Edmundo C. Grisard, ${ }^{2}$ \\ and Aguinaldo R. Pinto ${ }^{1 *}$ \\ ${ }^{1}$ Laboratório de Imunologia Aplicada, Departamento de Microbiologia e Parasitologia, UFSC, Florianópolis, SC, Brazil \\ ${ }^{2}$ Laboratórios de Protozoologia e de Bioinformática, Departamento de Microbiologia e Parasitologia, UFSC, \\ Florianópolis, SC, Brazil \\ ${ }^{3}$ Laboratório Avançado de Saúde Pública, Centro de Pesquisa Gonçalo Moniz (FIOCRUZ), Salvador, BA, Brazil \\ ${ }^{4}$ Escola Bahiana de Medicina e Saúde Pública/FBDC, Salvador, BA, Brazil \\ ${ }^{5}$ Hospital Regional Homero de Miranda Gomes, São José, SC, Brazil \\ ${ }^{6}$ Laboratório de Retrovírus, Instituto Adolfo Lutz, São Paulo, SP, Brazil
}

Recent studies have demonstrated an increased prevalence of human immunodeficiency virus type 1 (HIV-1) subtype C in southern Brazil. Although Santa Catarina State (SC) is located in this area and presents one of the country's highest incidences of HIV/AIDS, knowledge on the molecular epidemiology of HIV-1 in such State is lacking. The aim of this study was to investigate the HIV-1 molecular diversity and epidemiological profile of HIV-1-infected patients from SC. DNA samples were PCR amplified and HIV-1 subtypes were determined using both env and gag genes by direct sequencing. Phylogenetic analyses revealed that $48 \%$ were subtype $C$ and $23 \%$ were subtype $B$. Possible recombinant forms were observed for both $B / C$ $(23 \%)$ and $B / F(6 \%)$ subtypes. Our results, for the first time, identifies HIV-1 subtype $\mathrm{C}$ as a major clade circulating in SC and contributes to the understanding of HIV epidemics in the country by confirming the epidemic spread of the HIV-1 subtype $C$ in southern Brazil. J. Med. Virol. 79:1455-1463, 2007. ๑ 2007 Wiley-Liss, Inc.

KEY WORDS: AIDS; HIV; subtypes; Brazil

\section{INTRODUCTION}

Nowadays, around 40 million people are infected with human immunodeficiency virus type 1 (HIV-1), which can be characterized into three distinct groups named $\mathrm{M}, \mathrm{N}$, and $\mathrm{O}$. While HIV-1 strains belonging to the $\mathrm{O}$ and $\mathrm{N}$ groups show limited circulation in West Central Africa, group $M$ viruses are widely distributed and include the vast majority of HIV-1 strains responsible for the pandemic. Within group $M, 11$ subtypes (A-D,
$\mathrm{F}-\mathrm{H}$, and $\mathrm{J}-\mathrm{K}$ ) have been defined [McCutchan, 2006]. At least 34 circulating recombinant forms (CRFs) have now been identified along with a great variety of minor but equally important recombinant structures. In South America, previous molecular epidemiology studies have showed significant heterogeneity in the prevalence and geographic distribution of HIV subtypes. Most South American HIV-1 isolates belong to subtype $B$ and $F$, but co-circulation of diverse subtypes (A, C, and D) [Russell et al., 2000; Hierholzer et al., 2002; Soares et al., 2003a] and CRFs have been reported [Hierholzer et al., 2002; Carrion et al., 2003].

HIV diversity is basically due to independent but concurrent processes as follows: a high replication rate, frequent introduction of mutations, and recombination events [Coffin, 1995]. However, the biological relevance of HIV-1 genetic variability is not fully understood. It has been suggested that HIV-1 subtypes could be associated with different types of transmission [Soto-Ramirez et al., 1996]. The genetic variability of HIV also contributes to its capacity to evade host immune response and to gain resistance to antiretroviral drugs [Coffin, 1995]. Moreover, these differences may also have influence on cellular tropism, kinetics of viral replication, chemokine co-receptor usage, and disease progression [Arien et al., 2005]. Planning for a safe and effective vaccine against HIV-1 should probably consider epidemiologic data regarding

*Correspondence to: Aguinaldo R. Pinto, Departamento de Microbiologia e Parasitologia, UFSC, 88040-900 Florianópolis, SC, Brazil. E-mail: pintoar@ccb.ufsc.br

Accepted 12 June 2007

DOI 10.1002/jmv.20955

Published online in Wiley InterScience

(www.interscience.wiley.com) 
the distribution of HIV-1 subtypes in different regions of the world.

Brazil is the largest South American country and it is the most affected by the HIV/AIDS epidemics were about 600,000 Brazilians are infected with HIV-1 yielding an overall estimated prevalence of $0.6 \%$ [National Program on STD/AIDS et al., 2005]. Brazil has shown a constant change in its HIV-1 epidemic regarding gender infection ratio and risk behavior. Since the beginning of the epidemics, HIV infection patterns have shifted from homosexual individuals towards women and heterosexuals.

The major HIV-1 subtypes circulating in Brazil are $\mathrm{B}(75 \%)$ and $\mathrm{F}(10 \%)$, but other subtypes such as $\mathrm{C}$ and recombinant forms such as $\mathrm{B} / \mathrm{C}$ and $\mathrm{B} / \mathrm{F}$ have been documented [Louwagie et al., 1994; Sabino et al., 1996; Tanuri et al., 1999; Bongertz et al., 2000; Brindeiro et al., 2003; Soares et al., 2003b], except for the State of Santa Catarina. A high recombination process between subtypes $\mathrm{B}$ and $\mathrm{F}$ viruses has been subsequently reported [Thomson et al., 2004; Sa Filho et al., 2005]. Subtype C was first detected in Brazil by Csillag in the cities of Porto Alegre and São Paulo [Csillag, 1994]. Although subtype B is still commonly found nationwide, subtype C has been increasingly prevalent in the southern region [Soares et al., 2003a,b; Rodrigues et al., 2006], being responsible for $45 \%$ and $25 \%$ of the human infections in Rio Grande do Sul (RS) and Paraná (PR) States, respectively [Brindeiro et al., 2003]. However, no studies on the epidemiological analysis of HIV-1 in Santa Catarina State (SC) have been carried out.

Santa Catarina State has approximately six million people, is located in southern Brazil and share borders with PR and RS States as well as with Argentina (Fig. 1). Florianópolis, the capital of the SC, and vicinities comprise a metropolitan area with a population of over 800,000 inhabitants. AIDS incidence in SC was of 25.9 cases per 100,000 people in 2004 , being one of the highest incidences amongst the Brazilian States, having notified 14,712 AIDS cases up to December 2004 [National Program on STD/AIDS et al., 2005]. Although an increasing number of female cases have been reported, male infection represents $70 \%$ of the total cases. Despite the high incidence of HIV/AIDS in SC, data on the molecular epidemiology of such infection are lacking. The present study describes, for the first time, the molecular characterization as well as the epidemiological profile of HIV-1 infection in the SC State, southern Brazil.

\section{PATIENTS AND METHODS}

\section{Patients and Samples}

A total of 100 HIV-positive patients routinely attended at the HIV/AIDS State Reference Clinic at the Homero de Miranda Gomes Hospital in São José City ( $25 \mathrm{~km}$ from Florianópolis City) participated in the study from July to December of 2004. This unit is a public health center providing care to HIV-positive patients in São José and Florianópolis as well as for the satellite

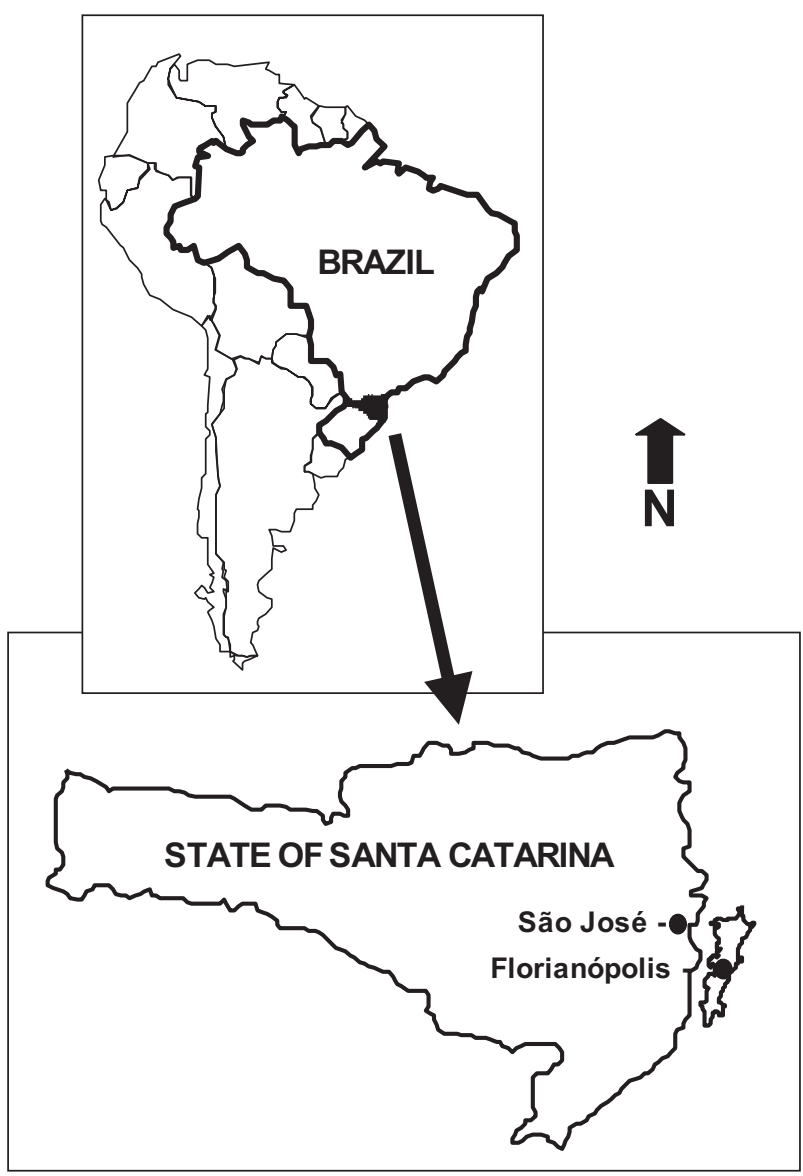

Fig. 1. Map of Brazil showing the Santa Catarina State and the localization of the Florianópolis and São José Cities.

cities. Inclusion criteria included age over 18-year old, CD4 counts superior to 200 cells $/ \mathrm{mm}^{3}$, availability of past and current medical records, and laboratory tests (viral load and CD4+ T-cell counts). HIV-proviral DNA samples were obtained from $5 \mathrm{ml}$ of peripheral blood cells of each patient and were processed on the same day for DNA extraction. For each patient, a standardized data form where the probable date of diagnosis, CD4 T-cell counts, and HIV viral load estimations, clinical information as well as past and current antiretroviral treatment regimens and their duration were recorded. All patients provided a written informed consent prior to blood specimen and data collection. The protocol was approved by the Ethics Committee of the Universidade Federal de Santa Catarina (UFSC).

\section{DNA Preparation and PCR Amplification of HIV-1 env and gag Gene Sequences}

Peripheral blood mononuclear cells (PBMC) were isolated by the Ficoll (Sigma-Aldrich, St. Louis, MO) gradient method and DNA was extracted by standard phenol/chloroform protocol after proteinase K $(100 \mu \mathrm{g})$ digestion [Sambrook and Russell, 2001]. HIV-1 env gene was amplified by a nested-PCR approach using primers 
ED5/ED12 and ES7/ES8 as the outer and inner primer sets, which amplify a 1,250 and 700 bp fragments, respectively. DNA samples revealing no amplification products using this protocol were further submitted to a second PCR using primers ED3/ED14 and ED31/ ED33, which resulted in amplicons of $2 \mathrm{kbp}$ and $640 \mathrm{bp}$, respectively [Delwart et al., 1994]. Amplifications were carried out with $\pm 1 \mu \mathrm{g}$ of total DNA/sample using three cycles of $94^{\circ} \mathrm{C}$ for $1 \mathrm{~min}, 55^{\circ} \mathrm{C}$ for $1 \mathrm{~min}$, and $72^{\circ} \mathrm{C}$ for $1 \mathrm{~min}, 32$ cycles of $94^{\circ} \mathrm{C}$ for $15 \mathrm{sec}, 55^{\circ} \mathrm{C}$ for $45 \mathrm{sec}, 72^{\circ} \mathrm{C}$ for $1 \mathrm{~min}$, and a final extension at $72^{\circ} \mathrm{C}$ for $5 \mathrm{~min}$ in a Mastercycler Gradient ${ }^{\circledR}$ thermal cycler (Eppendorf, Hamburg, Germany). For the nested-PCR amplification of the gag gene, primers HIG822/HIGHMA1317 (outer primer set) and H1Gag1584/g17 (inner primer set) were used for the amplification of an 830 and $460 \mathrm{bp}$ fragments, respectively. The amplification conditions were: $94^{\circ} \mathrm{C}$ for $2 \mathrm{~min}, 35$ cycles of $94^{\circ} \mathrm{C}$ for $30 \mathrm{sec}, 50^{\circ} \mathrm{C}$ for $30 \mathrm{sec}$, and $72^{\circ} \mathrm{C}$ for $1 \mathrm{~min}$ and a final extension for $7 \mathrm{~min}$ at $72{ }^{\circ} \mathrm{C}$ [Heyndrickx et al., 2000].

\section{DNA Sequencing}

A sample of $2 \mu \mathrm{l}$ of each nested-PCR products were precipitated with $70 \%$ isopropanol and directly sequenced using the DYEnamic ET Terminator Cycle sequencing kit (GE, Fairfield) in a MegaBace 1000 DNA Analysis System (GE). Sequencing was performed in triplicate for each sample and nested-PCR products obtained for the env and gag genes were sequenced using the ES7 and H1Gag1584 primers. Quality of the obtained sequences was analyzed by the Phred/ Phrap/Consed package and sequences with Phred $>20$ were visually inspected and edited. Identity and typing of the obtained sequences were checked by Blast similarity analysis using the Los Alamos National Laboratory (www.hiv-web.lanl.gov) database and by the REGA HIV-1 Automated Subtyping Tool [Oliveira et al., 2005], respectively. The env and gag nucleotide sequences reported in this study have been deposited in GenBank.

\section{Phylogenetic Analysis}

A multiple sequence alignment of the examined genetic region and the related sequences obtained from the GenBank/EMBL database (Reference sequences Accession Numbers: AF004885, AF005494, AF049495, $\mathrm{AF} 061640, \mathrm{AF} 077336, \mathrm{AF} 082394, \mathrm{AF} 082395, \mathrm{AF} 08$ 4936, AF110967, AF190127, AF190128, AF286228, AF286231, AJ249235, AJ249236, AJ249237, AJ249 239, AY162224, AY162223, K02007, K03454, K03455, M17451, M27323, M62320, U21135, U46016, U51190, U52953, U63632, U88822, AY727522, AY727524, AY 275523, AY13414, and outgroup AJ302647) was performed with the ClustalX program [Jeanmougin et al., 1998] and further edited with the GeneDoc program [Nicholas et al., 1997]. The substitution model was selected with Modeltest 3.06 program [Posada and Crandall, 1998]. Neighbor-joining (NJ) and maximumlikelihood (ML) phylogenetic analyses were performed with PAUP*4.0b10 program [Swofford et al., 1996]. The NJ trees were constructed with TrN substitution model including gamma distribution shape parameter and invariable sites (Fig. 2), and TVM substitution model including gamma distribution shape parameter (Fig. 3). The reliability of the NJ trees was evaluated by analyzing 1,000 bootstrap replicates. A likelihood ratio test was used to calculate the statistical support for the branches (expressed in $P$ values). Trees were drawn with the TreeView 1.4 program [Page, 1996].

\section{Statistical Analyses}

The Chi-squared test or Fisher's exact test was employed to evaluate possible correlation between HIV-1 subtype and demographic and clinical variables such as gender, clinical status, and laboratory variables (CD4 cell count and viral load). A $P$ level of 0.05 was defined as statistically significant.

\section{RESULTS}

\section{Epidemiological Features}

Table I summarizes the results of socio-demographic, clinical, and laboratorial data of the HIV-1 infected patients included in the present study. Among all obtained samples, 20 (20\%) revealed no PCR amplification or presented weak amplifications for either genomic region (gag or env) and thus were excluded from the analysis. From a total of 80 patients, 44 were females (55\%) and 36 males (45\%), with a mean 38.7 years of age. The mean estimated length of probable HIV infection was 6.2 years. Median of HIV RNA level was 10,191 copies/ml. A large range of viral load was observed, ranging from undetectable ( $<80$ copies $/ \mathrm{ml}$ ) to over $10^{5}$ copies $/ \mathrm{ml}$. Median of CD4 cell count was 532 cell $\mathrm{s} / \mathrm{mm}^{3}$, and according to the CD4 T cell counting, patients were classified in two groups: patients with $>500$ cells $/ \mathrm{mm}^{3}(46.3 \%)$ and patients with cell CD4 between 200 and 500 cells $/ \mathrm{mm}^{3}(53.7 \%)$. In addition, by the time of sample collection, $53 \%$ of patients were on antiretroviral drug treatment, and the remaining (27\%) was treatment-naive or had received treatment in the past. The infection was mainly acquired through heterosexual exposure (79\%), followed by intravenous drug use (10\%), homosexual exposure (8.5\%), and by blood transfusion $(2.5 \%)$.

\section{HIV-1 Subtyping and Phylogenetic Analysis}

We have identified by Blast and REGA HIV-1 analysis, based on env and gag genomic regions, among the 80 samples the occurrence of $45(56.25 \%)$ and $51(63.75 \%)$ of subtype $\mathrm{C}$ virus, $32(40 \%)$ and 27 $(33.75 \%)$ subtype B, and $3(3.75 \%)$ and $2(2.5 \%)$ subtype F, respectively. Following analysis of both genomic regions (env and gag) simultaneously, 23 sequences showed evidence of subtype divergence between two of these subtypes (B, C, and F). Both Blast similarity analysis and the REGA HIV-1 subtyping tool [Oliveira et al., 2005] allowed the detection four possible mixed 


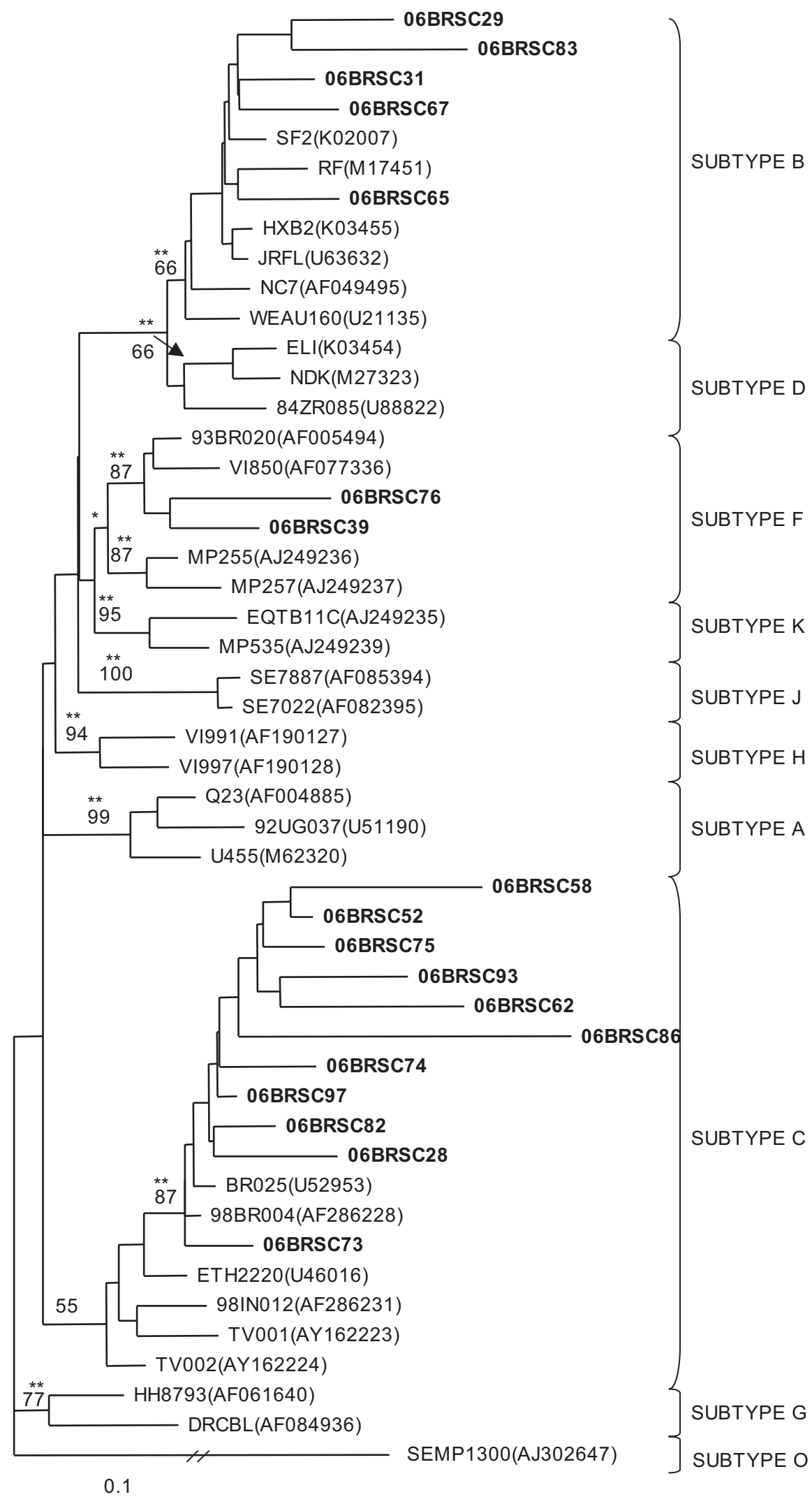

Fig. 2. Rooted NJ tree of 18 new HIV-1 gag sequences. The bootstrap values (above $50 \%$ and using 1,000 bootstrap) on the branches represent the percentage of trees in which the sequences at the right end of the branch form a monophyletic group. SEMP1300 (AJ302647) was used as outgroup. Newly gag sequences included in this analysis (in bold) are the following Florianópolis and São José isolates. The ** means that the ML method was highly significant with a $P$ value $<0.001$ or significant with a $P$ value $<0.005$. 


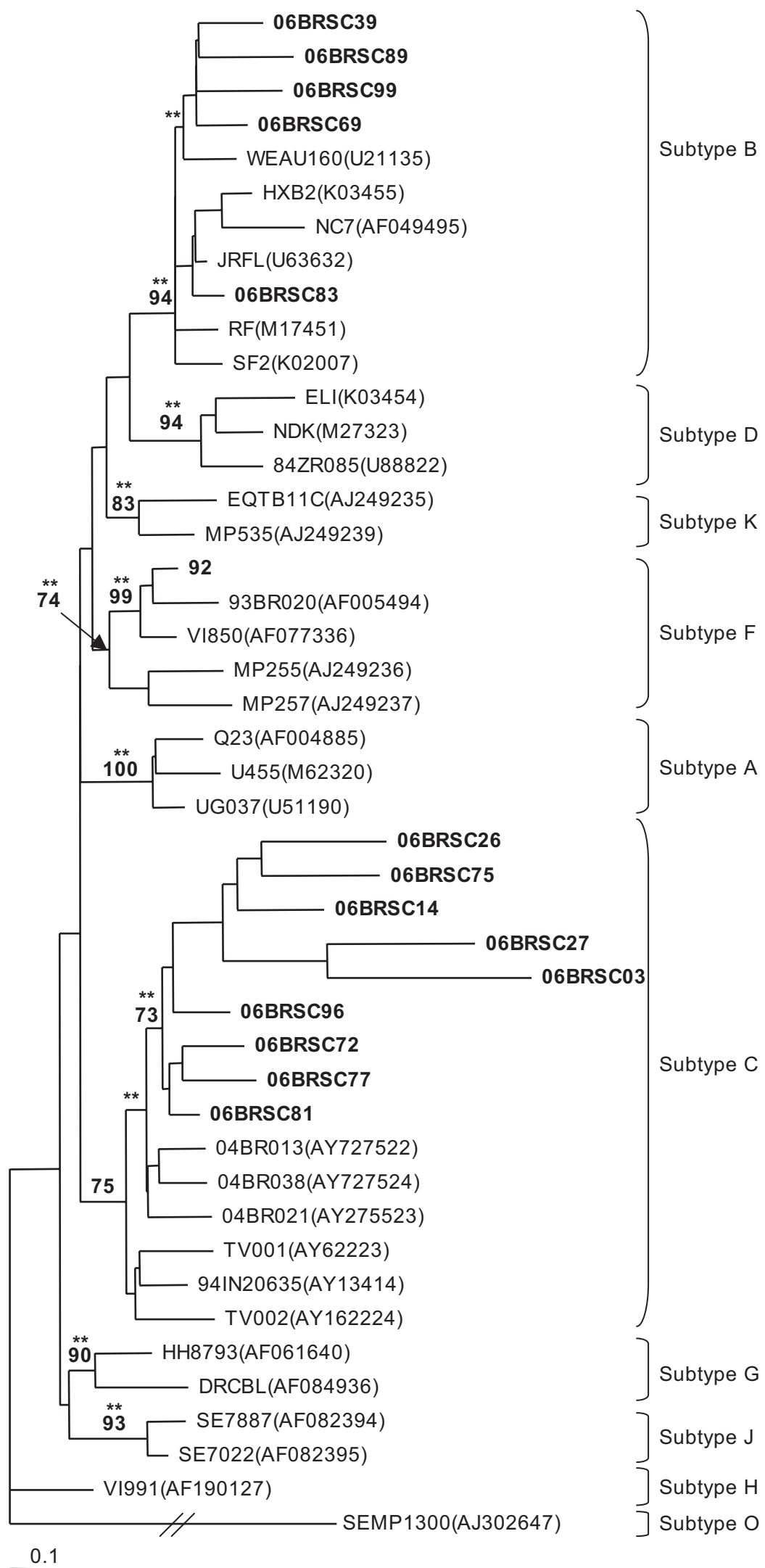

Fig. 3. Rooted NJ tree of 15 new HIV-1 env sequences. The bootstrap values (above $50 \%$ and using 1,000 bootstrap) on the branches represent the percentage of trees in which the sequences at the right end of the branch form a monophyletic group. SEMP1300 (AJ302647) was used as outgroup. Newly env sequences included in this analysis (in bold) are the following Florianópolis and São José isolates. The ** means that the ML method was highly significant with a $P$ value $<0.001$ or significant with a $P$ value $<0.005$. 
TABLE I. Distribution of the Epidemiological Data of the HIV-1 Infected Individuals According to the Virus Subtyping*

\begin{tabular}{|c|c|c|c|c|c|}
\hline & $\begin{array}{c}\text { Total } \\
(\mathrm{n}=80)\end{array}$ & $\begin{array}{c}\text { Subtype B } \\
(\mathrm{n}=18)\end{array}$ & $\begin{array}{c}\text { Subtype C } \\
(\mathrm{n}=39)\end{array}$ & $\begin{array}{l}\text { Subtype B/C } \\
\quad(\mathrm{n}=18)\end{array}$ & $\begin{array}{c}\text { Subtype B/F } \\
(\mathrm{n}=5)\end{array}$ \\
\hline Mean age (years) $\pm \mathrm{SD}$ & $38.7 \pm 10.3$ & $43.9 \pm 15.2$ & $37.1 \pm 8.8$ & $40.5 \pm 7.8$ & $35.2 \pm 9.3$ \\
\hline \multicolumn{6}{|l|}{$\operatorname{Sex}(\%)$} \\
\hline Male & $36(45 \%)$ & $8(44 \%)$ & $17(44 \%)$ & $9(50 \%)$ & $3(60 \%)$ \\
\hline Female & $44(55 \%)$ & $10(56 \%)$ & $22(56 \%)$ & $9(50 \%)$ & $2(40 \%)$ \\
\hline Mean diagnosis time (years) $\pm \mathrm{SD}$ & $6.2 \pm 4.6$ & $5.9 \pm 3.9$ & $6.1 \pm 4.9$ & $6.5 \pm 4.9$ & $6.4 \pm 4.6$ \\
\hline \multicolumn{6}{|l|}{ Exposure categories } \\
\hline Heterosexual & $63(79 \%)$ & 12 & 29 & 18 & 4 \\
\hline Injection drug user & $8(10 \%)$ & 4 & 4 & - & - \\
\hline Homosexual & $7(8 \%)$ & 2 & 4 & - & 1 \\
\hline Transfusion & $2(3 \%)$ & - & 2 & - & - \\
\hline \multicolumn{6}{|l|}{ Mean CD4 T-cell count \pm SD } \\
\hline Treated & $510 \pm 173.4$ & $531 \pm 131.7$ & $499 \pm 179.8$ & $539 \pm 223.4$ & $400 \pm 62.7$ \\
\hline Non-treated & $553 \pm 267.7$ & $564 \pm 81.9$ & $598 \pm 245.7$ & $468 \pm 193.9$ & $516 \pm 72.6$ \\
\hline \multicolumn{6}{|l|}{ Mean particles viral/ml } \\
\hline Treated & 8,114 & 2,027 & 14,978 & 1,082 & 5,100 \\
\hline Non-treated & 12,268 & 12,495 & 8,242 & 21,023 & 9,350 \\
\hline \multicolumn{6}{|l|}{ Treatment status (\%) } \\
\hline Treated & 53 & 14 & 25 & 11 & 3 \\
\hline Non-treated & 27 & 4 & 14 & 7 & 2 \\
\hline
\end{tabular}

*All statistical comparisons were not significant unless otherwise stated in the text.

patterns as follows: 12 samples were env $\mathrm{B} / g a g \mathrm{C}, 6$ env $\mathrm{C} /$ gag $\mathrm{B}, 3$ env $\mathrm{F} / g a g \mathrm{~B}$, and 2 env $\mathrm{B} / g a g \mathrm{~F}$. These represented $28.75 \%$ of the 80 samples analyzed in both genomic regions and reinforce the indication of recombination events. Among the 32 samples identified as subtype B by env gene typing, 7 presented the typical GWGR motif in the loop V3 (positions 7152-7154, relative to HXB2), commonly observed for the Brazilian subtype B samples (data not shown). Additionally, phylogenetic analysis of the HIV-1 gag region (Fig. 2) revealed that 11 (61\%) out of eighteen new Brazilian sequences clustered into the subtype $\mathrm{C}$ as supported by both bootstrap of $87 \%$ and ML analysis with $P<0.001$. Two (11\%) of them were classified as subtype F (bootstrap 87\%, ML $P<0.001$ ) and five $(28 \%)$ of them clustered into the subtype B (bootstrap 66\%, ML $P<0.001$ ). A similar phylogenetic analysis carried out for the HIV-1 env region (Fig. 3) showed that $9(60 \%)$ out of 15 new Brazilian sequences clustered into the subtype $\mathrm{C}$ as supported by bootstrap of $75 \%$. One $(7 \%)$ of them clustered into the subtype F (bootstrap 74\%, ML $P<0.001$ ) and four $(27 \%)$ of them grouped into the subtype B (bootstrap 94\%, ML $P<0.001$ ). In both topologies, the subtype $\mathrm{C}$ query sequences revealed a close relationship between the Brazilian subtype $\mathrm{C}$ sequences as supported by bootstrap values and ML analyses.

\section{Epidemiological and Laboratory Data Versus HIV-1 Subtyping}

Data from patients infected by HIV-1 subtypes B, C, $\mathrm{B} / \mathrm{C}$, or $\mathrm{B} / \mathrm{F}$ are summarized in the Table I. Due to the small sample size, the herein presented data are descriptive but reveals some differences among the subtypes occurring in the SC State. A higher frequency of HIV-1 subtype C was found in every exposure categories. No statistically significant differences were found between CD4 cell counts, viral load, mean age, and HIV-1 subtypes ( $P$ values of $0.1509,0.2710$, and 0.3411 , respectively) among all studied patients.

\section{DISCUSSION}

The present study shows a high prevalence of HIV-1 subtype C in SC State, Southern Brazil. While previous reports have suggested an increasing prevalence of subtype C in the south of Brazil [Brindeiro et al., 2003; Soares et al., 2003b], they have not included samples from the SC State. Our results indicate that subtype C is predominant $(48.75 \%)$ among the analyzed samples, increasing to $71.25 \%$ when the recombinant viruses containing subtype C-related sequences are considered. Nevertheless, a relatively high proportion of HIV-1 subtype B $(22.5 \%)$ as well as possible recombinant forms $\mathrm{B} / \mathrm{C}$ and $\mathrm{B} / \mathrm{F}(28.75 \%)$ are circulating in the studied State. The prevalence of subtype C in SC State is in agreement with the overall prevalence of $45 \%$ reported by Brindeiro et al. [2003] for southern Brazil.

Identification of the subtype $\mathrm{C}$ was first reported in the Southern region in 1994 [Csillag, 1994], suggesting a possible later introduction of this viral subtype when compared to subtype B. Previous surveys in Brazil have shown frequencies of approximately $3 \%$ for subtype C viruses in the country [Bongertz et al., 2000]. The prevalence of subtype $\mathrm{C}$ reaches a remarkable $45 \%$ frequency of the viruses in the City of Rio Grande, RS State [Soares et al., 2005], and even higher frequency (58\%) in Porto Alegre City, RS [Rodrigues et al., 2006], where it was first detected. The high prevalence of subtype $\mathrm{C}$ samples decreases northbound: the prevalence was 24\% in PR State and 3\% in São Paulo (SP) State [Brindeiro et al., 2003]. These findings corroborate our results and show that the distribution of HIV-1 genetic subtypes currently assumes different patterns 
in distinct regions of the country, being subtype B most common in Southeast and Northeast regions, and subtype $\mathrm{C}$ prevailing over subtype $\mathrm{B}$ in southern Brazil [Morgado et al., 2002]. HIV-1 subtype C has been recently detected in Paraguay, Uruguay, and Argentina [Carrion et al., 2004], and a recent predominance of subtype $\mathrm{C}$ over other subtypes has been described in many other countries [Renjifo et al., 1998; Rodenburg et al., 2001; Shankarappa et al., 2001]. Although it has been proposed that subtype $\mathrm{C}$ is actually less fit than subtype B in vitro [Ball et al., 2003], these findings have not been supported in vivo. Salemi et al. reported that subtype $\mathrm{C}$ is spreading two times faster than subtype $\mathrm{B}$ in Southern Brazil. This may reflect a difference in the efficiency of different transmission routes in distinct geographical areas [Salemi et al., 2005].

Several studies of HIV diversity in Brazil have shown the presence of HIV-1 subtypes B, C, D, and F [Morgado et al., 2002], B/F and B/C recombinant viruses [Guimaraes et al., 2002a; Brindeiro et al., 2003] as well as dual infections [Ramos et al., 1999]. A similar percentage of recombinant forms reported by Brindeiro et al. [2003] in RS State in 2001-2002 (22\%) was observed in the present study (28.75\%) in the SC State. Despite this similar subtype prevalence, $6.25 \%$ of the samples observed in our study indicates the occurrence of recombinants $\mathrm{B} / \mathrm{F}(2$ env $\mathrm{B} / g a g \mathrm{~F}$ and 3 env $\mathrm{F} / g a g \mathrm{~B})$ and $22.5 \%$ recombinants $\mathrm{B} / \mathrm{C}(12$ env $\mathrm{B} / \operatorname{gag} \mathrm{C}$ and 6 env $\mathrm{C} /$ gagB), which is in accordance with previous studies in southern Brazil. Although we found recombinant B/F subtypes, we were not able to find individuals with single subtype $\mathrm{F}$ infection, possibly due the small sample size. Nevertheless, a full-length genome study is required to confirm these preliminary observations. The high prevalence of HIV-1 subtype C viruses in the south and south-eastern parts of Brazil, regions with similar high prevalence of subtype B viruses, has probably allowed a high number of recombination events between these two subtypes. This observation can be demonstrated by a large number of $\mathrm{B} / \mathrm{C}$ recombinants $(22.5 \%)$ observed among the mosaic viruses analyzed in our dataset, especially when compared with the $\mathrm{B} / \mathrm{F}$ recombinant (6.25\%). A more recent introduction of HIV-1 subtype $\mathrm{F}$ in Brazil is consistent with the lower prevalence and genetic variability of this subtype in the Brazilian epidemic [Louwagie et al., 1994; Pinto et al., 1998; Bongertz et al., $2000]$. Subtype F variant is spread all over the country and corresponds approximately to $10 \%$ of the samples analyzed in Rio de Janeiro and São Paulo Cities, and recombinant forms of subtype $B$ and $F$ have been described previously [Louwagie et al., 1994; Ramos et al., 1999].

The associations of HIV-1 subtype F infection with endogenous drug users and females, subtype B among homosexuals, and subtype $\mathrm{C}$ among heterosexuals has been previously suggested [Sabino et al., 1996; Soto-Ramirez et al., 1996; Rossini et al., 2001]. In the present study, no correlation between HIV-1 subtypes, gender, age, and laboratorial parameters was observed.
In addition to the small sample size that provides low power to many comparisons, another important factor to be considered is the single source of the samples, which were collected from only one particular center, raising the question of how representative the samples are for the State of Santa Catarina. Although this is not a randomized study, this hospital is the largest HIV/AIDS reference center in the SC State, performing diagnosis, treatment as well as follow-up of a large proportion of all cases of HIV in the state, with approximately 1,000 patients being currently followed. The observed broad diversity of HIV-1 subtypes circulating in the SC State could be, in part, attributed to tourism activities. Santa Catarina State is a very important tourist destination, attracting people from different regions, specially from the vicinities areas, as Rio Grande do Sul State, Argentina and Uruguay, where subtype C has been already detected [Brindeiro et al., 2003; Carrion et al., 2004; Rodrigues et al., 2006]. Also, one of the largest sea ports in Brazil is located in SC, and that may also be responsible for the viral diversity in the region.

The herein presented data are the first report on molecular characterization of HIV-1 subtypes circulating in SC State, and it is in accordance with previous studies, which demonstrated an increasing pattern of the HIV-1 clade $\mathrm{C}$ prevalence in other southern Brazilian States. The close relationship between the query sequences and the Brazilian reference sequence suggest that subtype C was recently introduced in the Santa Catarina State, which is in agreement with previous studies about HIV subtype $\mathrm{C}$ in southern Brazil [Guimaraes et al., 2002a,b; Soares et al., 2003a]. Despite the reduced number of samples, we have also detected a quite high frequency of a recombinant $\mathrm{B} / \mathrm{C}$ and $\mathrm{B} / \mathrm{F}$ subtypes, suggesting the presence of a spectrum of recombination between these subtypes in the studied population. Southern Brazil is the only region in the country where the HIV/AIDS epidemic has been increasing [National Program on STD/AIDS et al., 2005], and the association of this growth and subtype $\mathrm{C}$ viruses should be further investigated. Furthermore, our results may contribute to the understanding of the dynamics of the HIV-1 epidemic spreading into the Brazilian population, providing information that can be useful in planning control actions, intervention strategies and development of appropriate and effective vaccines.

\section{ACKNOWLEDGMENTS}

This study was supported by Conselho Nacional de Desenvolvimento Científico e Tecnológico $(\mathrm{CNPq})$ and Programa Nacional de DST/AIDS, Ministério da Saúde, Brazil. P.H. Stoco is recipient of a CAPES scholarship.

\section{REFERENCES}

Arien KK, Troyer RM, Gali Y, Colebunders RL, Arts EJ, Vanham G. 2005. Replicative fitness of historical and recent HIV-1 isolates suggests HIV-1 attenuation over time. AIDS 19:1555-1564.

Ball SC, Abraha A, Collins KR, Marozsan AJ, Baird H, QuinonesMateu ME, Penn-Nicholson A, Murray M, Richard N, Lobritz M, 
Zimmerman PA, Kawamura T, Blauvelt A, Arts EJ. 2003 Comparing the ex vivo fitness of CCR5-tropic human immunodeficiency virus type 1 isolates of subtypes B and C. J Virol 77:10211038.

Bongertz V, Bou-Habib DC, Brigido LF, Caseiro M, Chequer PJ, CoutoFernandez JC, Ferreira PC, Galvao-Castro B, Greco D, Guimaraes ML, Linhares de Carvalho MI, Morgado MG, Oliveira CA, Osmanov S, Ramos CA, Rossini M, Sabino E, Tanuri A, Ueda M. 2000. HIV-1 diversity in Brazil: Genetic, biologic, and immunologic characterization of HIV-1 strains in three potential HIV vaccine evaluation sites. Brazilian network for HIV isolation and characterization. J Acquir Immune Defic Syndr 23:184-193.

Brindeiro RM, Diaz RS, Sabino EC, Morgado MG, Pires IL, Brigido L, Dantas MC, Barreira D, Teixeira PR, Tanuri A. 2003. Brazilian Network for HIV Drug Resistance Surveillance (HIV-BResNet): A survey of chronically infected individuals. AIDS 17:10631069.

Carrion G, Hierholzer J, Montano S, Alava A, Perez J, Guevara A, Laguna-Torres V, Mosquera C, Russell K, Chauca G, Kochel T, Birx DL, Sanchez JL, Carr JK. 2003. Circulating recombinant form CRF02 AG in South America. AIDS Res Hum Retroviruses 19: $329-3 \overline{32}$.

Carrion G, Eyzaguirre L, Montano SM, Laguna-Torres V, Serra M, Aguayo N, Avila MM, Ruchansky D, Pando MA, Vinoles J, Perez J, Barboza A, Chauca G, Romero A, Galeano A, Blair PJ, Weissenbacher M, Birx DL, Sanchez JL, Olson JG, Carr JK. 2004. Documentation of subtype C HIV Type 1 strains in Argentina, Paraguay, and Uruguay. AIDS Res Hum Retroviruses 20:10221025.

Coffin JM. 1995. HIV population dynamics in vivo: Implications for genetic variation, pathogenesis, and therapy. Science 267:483489.

Csillag C. 1994. HIV-1 subtype C in Brazil. Lancet 344:1354.

Delwart EL, Sheppard HW, Walker BD, Goudsmit J, Mullins JI. 1994. Human immunodeficiency virus type 1 evolution in vivo tracked by DNA heteroduplex mobility assays. J Virol 68:66726683.

Guimaraes ML, dos Santos Moreira A, Loureiro R, Galvao-Castro B, Morgado MG. 2002a. High frequency of recombinant genomes in HIV type 1 samples from Brazilian southeastern and southern regions. AIDS Res Hum Retroviruses 18:1261-1269.

Guimaraes ML, Moreira AS, Morgado MG. 2002b. Polymorphism of the Human Immunodeficiency Virus Type 1 in Brazil: Genetic characterization of the nef gene and implications for vaccine design. Mem Inst Oswaldo Cruz 97:523-526.

Heyndrickx L, Janssens W, Zekeng L, Musonda R, Anagonou S, Van der Auwera G, Coppens S, Vereecken K, De Witte K, Van Rampelbergh R, Kahindo M, Morison L, McCutchan FE, Carr JK, Albert J, Essex M, Goudsmit J, Asjo B, Salminen M, Buve A, van Der Groen G. 2000. Simplified strategy for detection of recombinant human immunodeficiency virus type 1 group $\mathrm{M}$ isolates by gag/env heteroduplex mobility assay. Study Group on Heterogeneity of HIV Epidemics in African Cities. J Virol 74:363-370.

Hierholzer J, Montano S, Hoelscher M, Negrete M, Hierholzer M, Avila MM, Carrillo MG, Russi JC, Vinoles J, Alava A, Acosta ME, Gianella A, Andrade R, Sanchez JL, Carrion G, Russell K, Robb M, Birx D, McCutchan F, Carr JK. 2002. Molecular epidemiology of HIV Type 1 in Ecuador, Peru, Bolivia, Uruguay, and Argentina. AIDS Res Hum Retroviruses 18:1339-1350.

Jeanmougin F, Thompson JD, Gouy M, Higgins DG, Gibson TJ. 1998. Multiple sequence alignment with Clustal X. Trends Biochem 23:403-405.

Louwagie J, Delwart EL, Mullins JI, McCutchan FE, Eddy G, Burke DS. 1994. Genetic analysis of HIV-1 isolates from Brazil reveals presence of two distinct genetic subtypes. AIDS Res Hum Retroviruses 10:561-567.

McCutchan FE. 2006. Global epidemiology of HIV. J Med Virol 78 S7S12.

Morgado MG, Guimaraes ML, Galvao-Castro B. 2002. HIV-1 polymorphism: A challenge for vaccine development-a review. Mem Inst Oswaldo Cruz 97:143-150.

National Program on STD/AIDS BMoH, Brazil. 2005. Epidemiologic bulletin-AIDS year II no. 01. January to July.

Nicholas KB, Nicholas HBJ, Deerfield DW. 1997. GeneDoc: Analysis and visualization of genetic variation (EMBNEW NEWS 30).

Oliveira T, Deforche K, Cassol S, Salminem M, Paraskevis D, Seebregts C, Snoeck J, van Rensburg EJ, Wensing AMJ, van de Vijver DA,
Boucher CA, Camacho R, Vandamme AM. 2005. An automated genotyping system for analysis of HIV-1 and other microbial sequences. Bioinfomatics 21:3797-3800.

Page RD. 1996. TreeView: An application to display phylogenetic trees on personal computers. Comput Appl Biosci 12:357-358.

Pinto ME, Tanuri A, Schechter M. 1998. Molecular and epidemiologic evidence for the discontinuous introduction of subtypes B and F into Rio de Janeiro, Brazil. J Acquir Immune Defic Syndr 19:310312.

Posada D, Crandall KA. 1998. MODELTEST: Testing the model of DNA substitution. Bioinformatics 14:817-818.

Ramos A, Tanuri A, Schechter M, Rayfield MA, Hu DJ, Cabral MC, Bandea CI, Baggs J, Pieniazek D. 1999. Dual and recombinant infections: An integral part of the HIV-1 epidemic in Brazil. Emerg Infect Dis 5:65-74

Renjifo B, Chaplin B, Mwakagile D, Shah P, Vannberg F, Msamanga G, Hunter D, Fawzi W, Essex M. 1998. Epidemic expansion of HIV type 1 subtype $\mathrm{C}$ and recombinant genotypes in Tanzania. AIDS Res Hum Retroviruses 14:635-638.

Rodenburg CM, Li Y, Trask SA, Chen Y, Decker J, Robertson DL, Kalish ML, Shaw GM, Allen S, Hahn BH, Gao F. 2001. Near fulllength clones and reference sequences for subtype C isolates of HIV type 1 from three different continents. AIDS Res Hum Retroviruses $17: 161-168$

Rodrigues R, Scherer LC, Oliveira CM, Franco HM, Sperhacke RD, Ferreira JL, Castro SM, Stella IM, Brigido LF. 2006. Low prevalence of primary antiretroviral resistance mutations and predominance of HIV-1 clade $\mathrm{C}$ at polymerase gene in newly diagnosed individuals from south Brazil. Virus Res 116:201207.

Rossini MA, Diaz RS, Caseiro M, Turcato G, Accetturi CA, Sabino EC 2001. HIV-1 subtypes among intravenous drug users from two neighboring cities in Sao Paulo State, Brazil. Braz J Med Biol Res 34:45-47.

Russell KL, Carcamo C, Watts DM, Sanchez J, Gotuzzo E, Euler A, Blanco JC, Galeano A, Alava A, Mullins JI, Holmes KK, Carr JK. 2000. Emerging genetic diversity of HIV-1 in South America. AIDS 14:1785-1791.

Sa Filho DJ, Sanabani S, Diaz RS, Munerato P, Brunstein A, Fusuma E, Sabino EC, Janini LM. 2005. Analysis of full-length human immunodeficiency virus type 1 genome reveals a variable spectrum of subtypes B and f recombinants in Sao Paulo, Brazil. AIDS Res Hum Retroviruses 21:145-151.

Sabino EC, Diaz RS, Brigido LF, Learn GH, Mullins JI, Reingold AL, Duarte AJ, Mayer A, Busch MP. 1996. Distribution of HIV-1 subtypes seen in an AIDS clinic in Sao Paulo City, Brazil. AIDS 10:1579-1584

Salemi M, de Oliveira T, Soares MA, Pybus O, Dumans AT, Vandamme AM, Tanuri A, Cassol S, Fitch WM. 2005. Different epidemic potentials of the HIV-1B and C subtypes. J Mol Evol 60:598605 .

Sambrook J, Russell DW. 2001. Molecular cloning: A laboratory manual. 3rd edition. New York: Cold Spring Harbor Laboratory Press. Vol 3, Appendix 8.

Shankarappa R, Chatterjee R, Learn GH, Neogi D, Ding M, Roy P, Ghosh A, Kingsley L, Harrison L, Mullins JI, Gupta P. 2001. Human immunodeficiency virus type 1 env sequences from Calcutta in eastern India: Identification of features that distinguish subtype $\mathrm{C}$ sequences in India from other subtype C sequences. J Virol 75:10479-10487.

Soares EA, Santos RP, Pellegrini JA, Sprinz E, Tanuri A, Soares MA. 2003a. Epidemiologic and molecular characterization of human immunodeficiency virus type 1 in southern Brazil. J Acquir Immune Defic Syndr 34:520-526.

Soares MA, De Oliveira T, Brindeiro RM, Diaz RS, Sabino EC, Brigido L, Pires IL, Morgado MG, Dantas MC, Barreira D, Teixeira PR, Cassol S, Tanuri A. 2003b. A specific subtype C of human immunodeficiency virus type 1 circulates in Brazil. AIDS 17: $11-21$.

Soares EA, Martinez AM, Souza TM, Santos AF, Da Hora V, Silveira J, Bastos FI, Tanuri A, Soares MA. 2005. HIV-1 subtype C dissemination in southern Brazil. AIDS 19:S81-S86.

Soto-Ramirez LE, Renjifo B, McLane MF, Marlink R, O'Hara C, Sutthent R, Wasi C, Vithayasai P, Vithayasai V, Apichartpiyakul C, Auewarakul P, Pena Cruz V, Chui DS, Osathanondh R, Mayer K Lee TH, Essex M. 1996. HIV-1 Langerhans' cell tropism associated with heterosexual transmission of HIV. Science 271:1291-1293. 
Swofford DL, Olsen GJ, Waddell PJ. 1996. Phylogenetic inference. Sunderland, MA: Sinauer Associates. 1996.

Tanuri A, Swanson P, Devare S, Berro OJ, Savedra A, Costa LJ, Telles JG, Brindeiro R, Schable C, Pieniazek D, Rayfield M. 1999. HIV-1 subtypes among blood donors from Rio de Janeiro, Brazil. J Acquir Immune Defic Syndr 20:60-66.
Thomson MM, Sierra M, Tanuri A, May S, Casado G, Manjon N, Najera R. 2004. Analysis of near full-length genome sequences of HIV type $1 \mathrm{BF}$ intersubtype recombinant viruses from Brazil reveals their independent origins and their lack of relationship to CRF12_BF. AIDS Res Hum Retroviruses 20:11261133. 